Gdańsk

\title{
Czynniki destabilizacji politycznej w Karaczajo-Czerkiesji: separatyzm etniczny i fundamentalizm religijny
}

\section{Uwagi wstępne}

aukaz Północny jest najbardziej niestabilnym regionem Federacji Rosyjskiej, który - może potencjalnie zagrozić bezpieczeństwu i integralności terytorialnej państwa. Nie sposób wymienić wszystkich aktualnych i potencjalnych ognisk konfliktów na tle etnicznym, klanowym, historycznym, kulturowym, religijnym i kryminalnym na tym terytorium. Choć władze w Moskwie podejmują wysiłki na rzecz normalizacji sytuacji w Północnokaukaskim Okręgu Federalnym, perspektywa długotrwałej stabilności politycznej i harmonijnej koegzystencji grup etnicznych nadal wydaje się bardzo odległa. Kaukaz Północny wchodzi w skład Federacji Rosyjskiej, lecz staje się coraz bardziej odległy od niej w aspekcie kulturowym, zyskując zarazem polityczną niezależność. Poszczególne republiki cieszą się znaczną autonomią, a niepodzielną władzę sprawują w nich elity etniczne i klanowe.

Dagestan, Czeczenia i Inguszetia są powszechnie uznawane za republiki, w przypadku których ryzyko dążeń secesjonistycznych i separatystycznych jest szczególnie wysokie. Lojalność tamtejszych elit politycznych wobec Moskwy jest często minimalna i wynika wyłącznie ze wspólnoty interesów, a nie wartości czy tożsamości. Popularność haseł separatystycznych, znaczne wpływy radykalnego islamu politycznego i złożona sytuacja etnopolityczna sprawiają, że terytoria regionów Kaukazu północno-wschodniego szczególnie często wymienia się w kontekście potencjalnych zagrożeń dla bezpieczeństwa narodowego Federacji Rosyjskiej. Błędem byłoby jednak sądzić, że północno-zachodnia część Kaukazu jest obszarem stabilności i harmonii. Niezliczone antagonizmy o charakterze etnoklanowym, ukryte animozje między przedstawicielami elit poszczególnych narodów, działalność ruchów separatystycznych, poczucie dziejowej krzywdy, systemowa korupcja, nepotyzm, niejasne powiązania między elitami politycznymi, gospodarczymi, klanowymi i kryminalnymi - wszystkie te czynniki czynią północno-zachodnią część Kaukazu obszarem szczególnie niestabilnym, stwarzającym potencjalne zagrożenie dla rosyjskiej państwowości.

Republika Karaczajo-Czerkiesja należy do najbardziej niestabilnych podmiotów Federacji Rosyjskiej. Choć, w odróżnieniu od Dagestanu czy Czeczenii, popularność idei radykalnego islamu politycznego jest tu niewielka, struktura etniczna charakteryzuje się nadzwyczajną złożonością, co nie znajduje odzwierciedlenia w modelu administracji terytorialnej. Skalę korupcji i nepotyzmu miejscowych elit należy uznać za ogromną. Największym zagrożeniem dla stabilności w regionie pozostają jednak odwieczne animozje między etnosami i klanami oraz coraz większe wpływy organizacji separatystycznych, przede wszystkim ruchu panczerkieskiego.

Relacje między obydwoma etnosami tytularnymi Karaczajo-Czerkiesji należy uznać za bardzo trudne, pełne wzajemnych uprzedzeń i nieufności, a często wręcz wrogości. Utworzo- 
ne 12 stycznia 1922 roku Karaczajewski i Czerkieski Obwód Autonomiczny długo funkcjonowały oddzielnie. Za początek koegzystencji obu narodowości w ramach wspólnej struktury administracyjnej należy uznać styczeń 1957 roku, gdy utworzony został Karaczajo-Czerkieski Obwód Autonomiczny ${ }^{1}$.

Istniejący do dziś model republiki dwunarodowościowej jest elementem dziedzictwa radzieckiego - intencją jego wprowadzenia było przezwyciężanie partykularyzmów etnicznych. W zamyśle obie narodowości tytularne miały wzajemnie równoważyć swoje wpływy w republice. Mechanizm równowagi nie pozwoliłby którejkolwiek z nich na osiagnięcie pozycji hegemonicznej. Konieczność pracy na rzecz wspólnego dobra (dwunarodowościowej republiki) ponad podziałami etnicznymi miała położyć kres animozjom i umożliwić harmonijną koegzystencję grup narodowościowych. Istnienie republik dwunarodowościowych na Kaukazie (Karaczajo-Czerkieski Obwód Autonomiczny, Czeczeno-Inguszska i Kabardo-Bałkarska Autonomiczna Socjalistyczna Republika Radziecka) służyło budowaniu tożsamości ponadetnicznej i prymatowi lojalności wobec państwa radzieckiego nad partykularyzmami narodowościowymi i terytorialnymi.

Karaczajo-Czerkiesja jest sztucznym tworem politycznym. Karaczajów i Czerkiesów, dzieli niemal wszystko - pochodzenie etniczne, język, historia, kultura i tradycja. Można jednak wskazać dwa czynniki, które łączą obie te grupy narodowościowe. Pierwszym jest religia - islam sunnicki, do którego zasad przywiązuje się w regionie stosunkowo niewielką wagę. Zarówno Karaczajowie, jak i Czerkiesi łączą praktyki religijne z politeistycznymi i spirytualistycznymi tradycjami, etykietą i obrzędowością. Obchodzą święta muzułmańskie na równi z rytuałami wywodzącymi się z czasów pogańskich ${ }^{2}$. Drugim wspólnym komponentem tożsamości obu narodowości było poczucie udziału w radzieckim projekcie budowy cywilizacji socjalistycznej. Mieszkańcy Kaukazu Zachodniego w dość dużym stopniu internalizowali wartości radzieckie (kolektywizm, kult poświęcenia, skromność, niechęć do zachodniego stylu życia, poczucie przynależności do wspólnoty narodów ZSRR, duma z osiagnięć supermocarstwa) ${ }^{3}$, łącząc je z kulturą lokalną. Okres schyłku socjalistycznego imperium przyniósł erozję radzieckiego systemu wartości, a odrodzenie religijności następowało powoli. Pewnym substytutem powyższych czynników tworzących więź społeczną mogła stać się lojalność wobec państwa rosyjskiego. Ta nigdy jednak nie była zbyt silna na Kaukazie, nawet w jego zachodniej części. Schyłek radzieckiego modelu państwowości sprzyjał nastrojom etnicznego partykularyzmu i separatyzmu. Na przełomie lat osiemdziesiątych i dziewięćdziesiątych dotyczyło to w równym stopniu Karaczajów i Czerkiesów. Obecnie separatyzm karaczajski jest zjawiskiem marginalnym, podczas gdy wpływy ruchu panczerkieskiego systematycznie rosną, stwarzając coraz większe zagrożenie dla integralności terytorialnej Federacji Rosyjskiej.

\section{Narodziny i zmierzch separatyzmu karaczajskiego}

Początki karaczajskiego ruchu narodowego sięgają końca lat osiemdziesiątych. W okresie pierestrojki zaczęły powstawać pierwsze organizacje i fora polityczne, które domagały się pełnej rehabilitacji Karaczajów zesłanych w latach 1943-1957 oraz przywrócenia autonomii

\footnotetext{
${ }^{1}$ Zob. E. Matuszek, Narody pótnocnego Kaukazu. Historia-kultura-konflikty 1985-1991, Toruń 2007, s. 50.

${ }^{2}$ Ibidem, s. 105.

${ }^{3}$ Por. S. Kara-Murza, Sovetskaâ Civilizaciâ, Moskva 2001.
} 
Karaczei. Wśród nich wymienić można organizacje „Dżamagat”, „Demokratyczny Dżamagat” i Komitet Organizacyjny na rzecz Rehabilitacji. Organizacje głosiły hasła antyczerkieskie i antyrosyjskie. Poddawały bezpardonowej krytyce umiarkowaną politykę W. Chubijewa, uznawanego przez karaczajskich radykałów za moskiewskiego lojalistę ${ }^{4}$. Sam W. Chubijew choć był etnicznym Karaczajem, odżegnywał się od karaczajskiego partykularyzmu etnicznego. W czasach radzieckich opowiadał się za modelem koegzystencji wszystkich narodowości w ramach ZSRR i prymatem lojalności wobec uniwersalnej idei socjalizmu nad wąsko pojętą tożsamością etniczną i terytorialną. Po restauracji kapitalizmu w Rosji W. Chubijew pozostał orędownikiem polietnicznego modelu republiki, opowiadając się za równością wszystkich obywateli wobec prawa. Sprzeciwiał się nadawaniem którejkolwiek z narodowości szczególnych uprawnień. Uznawał, że system parytetów narodowościowych umocniłby etniczne partykularyzmy i utrudniłby realizację projektu nowoczesnej republiki wielonarodowościowej. Jego działania przyniosły tylko częściowy rezultat. W. Chubijew zapobiegł rozpadowi republiki i wojnie domowej. Nie zdołał jednak zapobiec pojawieniu się i wzrostowi znaczenia ruchów separatystycznych, które na stałe wpisały się w krajobraz polityczny Karaczajo-Czerkiesji.

W lipcu 1991 roku z inicjatywy „Demokratycznego Dżamagatu” odbył się Nadzwyczajny Zjazd Ludu Karaczajskiego. Podczas kongresu ogłoszono powstanie suwerennej Karaczajskiej Socjalistycznej Republiki Radzieckiej - Republiki Karaczaj. W grudniu 1991 roku powołano do życia Ogólnonarodową Radę Karaczaju, na której czele stanął prokurator Boris Batczajew. Nowy lider karaczajskich separatystów zainicjował serię wystąpień mających na celu uzyskanie autonomii przez Republikę Karaczaj. Hasła ruchu ulegały nieustannej radykalizacji. W czerwcu 1992 roku na zjeździe Ogólnonarodowej Rady Karaczaju wezwano do mobilizacji sił, mającej na celu odrodzenie państwowości karaczajskiej. Otwarcie głoszono hasła antyrosyjskie i separatystyczne. Gościem specjalnym konferencji był czeczeński prezydent Dżochar Dudajew. Karaczajscy separatyści nie zdołali jednak stworzyć trwałej siły politycznej. Lata 1993-1994 przyniosły schyłek popularności i wpływów karaczajskiego ruchu nacjonalistycznego ${ }^{5}$. Odrodzenie karaczajskiego ruchu nacjonalistycznego nastąpiło 14 kwietnia 1998 roku podczas zjazdu zjednoczeniowego karaczajskich organizacji nacjonalistycznych. Podczas kongresu powołano do życia karaczajskie stowarzyszenie „Ałan”, na którego czele stanął przedsiębiorca Achmat Katczijew. Zastępcą przewodniczącego organizacji został dawny przywódca Ogólnonarodowej Rady Karaczei B. Batczajew. Organizacja nie głosiła otwarcie haseł separatystycznych - ograniczała się do haseł o karaczajskim odrodzeniu narodowym. Separatyzm karaczajski nie ma obecnie perspektyw rozwoju, ponieważ przedstawiciele tego tureckiego etnosu dominują w elitach politycznych republiki już od czasów radzieckich, a ich dominację ostatecznie potwierdziły wydarzenia podczas kryzysu 1999 roku, który zakończył się klęską czerkieskiego ruchu narodowego. Karaczajskiej hegemonii nie naruszyły także rządy Borisa Ebziejewa, liberała i przeciwnika etnokracji. Status quo wydaje się korzystne dla Karaczajów co sprawia, że perspektywy zaistnienia w regionie silnego ruchu separatystycznego odwołującego się do karaczajskiego nacjonalizmu separatystycznego są nader wątłe. Postulaty separatystyczne cieszą się zaś rosnącą popularnością wśród Czerkiesów.

\footnotetext{
${ }^{4}$ Zob. T. Muzajev, Vybory glavy Karačaevo- Čerkiesii. Ot političeskogo protivostojaniâ k meŽnacional'nomu konfliktu, http://igpi.ru/monitoring/1047645476/1999/0599/9.html (15.01.2012).

5 Ibidem.
} 


\section{Separatyzm panczerkieski - największe zagrożenie dla stabilności regionalnej}

Nacjonalizm panczerkieski (adygski) należy do najsilniejszych nurtów separatystycznych nie tylko na Kaukazie Północnym, ale i na całym terytorium Federacji Rosyjskiej. Jego celem jest przezwyciężenie partykularyzmów etnicznych w imię utworzenia na wschodnim wybrzeżu Morza Czarnego wspólnego państwa Abchazów, Adygejczyków, Czerkiesów, Kabardyjczyków, Abazyjczyków i Szapsugów. Mniej radykalni działacze panczerkiescy domagają się utworzenia autonomicznego podmiotu Federacji Rosyjskiej, który obejmowałby terytoria zamieszkałe przez ludy abchazo-adygskie. Tzw. ,problem czerkieski” wymienia się wśród najpoważniejszych zagrożeń dla integralności terytorialnej Federacji Rosyjskiej, a jego opis wykracza poza problematykę niniejszej pracy. Nie sposób jednak nie zauważyć, że Republika Karaczajo-Czerkiesja pozostaje jednym z najistotniejszych centrów działalności separatystów panczerkieskich. „Problem czerkieski” zostanie omówiony w takim zakresie, w jakim dotyczy elit politycznych republiki.

Historię ruchu panczerkieskiego należy wiązać z postacią dziewiętnastowiecznego brytyjskiego awanturnika i wywiadowcy Davida Urquharta działającego w regionie Kaukazu. Jego celem było włączenie pasa między Morzem Czarnym i Morzem Kaspijskim w brytyjską strefę wpływów. D. Urquhart podjął działania mające na celu wyparcie Rosjan z Kaukazu. Kluczem do realizacji tego przedsięwzięcia miała być integracja zatomizowanych plemion górskich zamieszkujących wschodnie wybrzeże Morza Czarnego poprzez stworzenie tożsamości narodowej łączącej wszystkich Adygów (Czerkiesów), na bazie której będzie mógł powstać ruch nacjonalistyczny o orientacji probrytyjskiej i antyrosyjskiej. Brytyjski wywiadowca stworzył zręby ideologii panczerkieskiej, był także twórcą projektu czerkieskiego zielonego sztandaru ze złotymi skrzyżowanymi strzałami i gwiazdamí.

Według nacjonalistów panczerkieskich, przedstawiciele wszystkich etnosów określających się jako „Adyge” są w istocie jednym narodem, który wskutek wieloletniej polityki władz carskiej i radzieckiej Rosji został podzielony i rozsiedlony. Celem ruchu jest przywrócenie jedności Adygów, zbudowanie ich tożsamości narodowej w oparciu o wspólną świadomość historyczną, a następnie wysunięcie postulatów autonomii i niepodległości. Pierwszym krokiem do samostanowienia musi być jednak przezwyciężenie podziałów. Stanowisko działaczy panczerkieskich wyraził Zamir Szuchow w wywiadzie udzielonym Awromowi Szmulewiczowi:
Rozdrobnienie nas, Czerkiesów, na spokrewnione narody było decyzja polityczna, która nie miała nic wspólnego z etnografia. Z każdego punktu widzenia jesteśmy jednym naro- dem. [...] Oficjalnie, w dokumentach rosyjskojęzycznych, postugujemy się etnonimem „Czerkiesi” i chcemy, by w podczas następnego spisu powszechnego w Federacji Rosyj- skiej wszyscy Adygowie uznali się za Czerkiesów. W dokumentach w języku czerkieskim postugujemy się etnonimem „Adyge”, który można przetlumaczyć jako ,ludzie Stońca”, .

Państwo Adygów miałoby obejmować terytorium historycznej Czerkiesji (dzisiejsza Adygeja, Karaczajo-Czerkiesja, Kabardo-Bałkaria oraz część Kraju Krasnodarskiego i Kraju Krasnodarskiego), niezależnego regionu położonego na pograniczu dwóch wielkich imperiów - Rosyjskiego i Osmańskiego.

\footnotetext{
${ }^{6}$ Zob. C. King, Imagining Circassia: David Urquhart and the Making of North Caucasus Nationalism, „Russian Review" 2007, nr 66, s. 238-255.

${ }^{7}$ M. Budaj, ,,Velikâ̂ Čerkesiâ” - poslednij šag k razvalu Rossii, Karacaevsk 2011, s. 273.
} 
To, w jakim stopniu dzisiejsze ludy adygskie są spadkobiercami historycznych Czerkiesów, pozostaje kwestią sporną (część autorów utrzymuje że historyczni Czerkiesi byli ludem tureckim $)^{8}$. Tożsamość narodowa często jest budowana w oparciu o mity, a nie o rzeczywiste wydarzenia. Mit może stać się postawą trwałej więzi społecznej. Nacjonalizm adygski należy uznać za swoisty konstrukt będący rezultatem projektu politycznego. Panczerkieska „wspólnota wyobrażona" oparta jest o mit polityczny ludobójstwa narodu czerkieskiego ${ }^{9}$.

Swego rodzaju „,mitem założycielskim”, jednoczącym wszystkie narody adygskie miała stać się pamięć o ludobójstwie narodu czerkieskiego, którego Rosjanie mieli dokonać podczas stuletniej wojny rosyjsko-czerkieskiej, toczącej się z różną intensywnością w latach 1763-1864. Według działaczy panczerkieskich i sprzyjających im historyków podczas wojny miało zginąć 1,5 miliona Czerkiesów. Po zakończeniu wojny mieszkańcy obszaru zostali uznani za agentów Imperium Osmańskiego. Padli ofiarą czystki etnicznej - zostali zmuszeni do emigracji do Azji Mniejszej, Tracji i na Bliski Wschód. Dziewiętnastowieczna deportacja Czerkiesów określana jest terminem muhadżirstwo, oznaczającym przymusową emigrację. Czerkieskie muhadżirstwo stało się symbolem męczeństwa Adygów ${ }^{10}$. Propagowaną przez Czerkiesów wersję wydarzeń podważają historycy rosyjscy i karaczajscy, uznając, że na terenie Kaukazu toczyły się regularne działania wojenne, w których wszystkie strony dopuszczały się zbrodni. Kwestionują też masowy i planowy charakter mordów ${ }^{11}$. Niezależnie od tego, jaki charakter nosiły tragiczne wydarzenia na Kaukazie, przekonanie o istnieniu jednolitego narodu adygskiego oraz pamięć o „ludobójstwie Czerkiesów” stają się elementami świadomości zbiorowej narodowości abchazo-adygskich i są wykorzystywane w bieżącej walce politycznej.

Najsilniejszą panczerkieską organizacją nacjonalistyczną jest Międzynarodowe Stowarzyszenie Czerkieskie (Adyge Chase), stawiające sobie za cel zjednoczenie wszystkich Adygejczyków, Czerkiesów, Kabardyjczyków i Szapsugów, a także Abchazów i Abazyjczyków $^{12}$. Od 1989 roku organizacja działała nieformalnie - jej pierwszy oficjalny kongres odbył się w Nalczyku (stolicy Kabardo-Bałkarii) w maju 1991 roku. 24 października 1991 roku grupa wysunęła postulat oderwania terytorium zamieszkiwanego przez Czerkiesów (Republiki Czerkieskiej) i włączenie go na prawach autonomii do Kraju Stawropolskiego. W kolejnym roku liderzy organizacji zrezygnowali z postulatu i zaproponowali obsadzanie stanowisk republikańskich na zasadzie kwot (parytetów) etnicznych ${ }^{13}$.

Pierwszym liderem organizacji został najsłynniejszy czerkieski działacz polityczny Jurij Chamzatowicz Kałmykow, urodzony w 1934 roku w Batałpaszińsku na terenie ówczesnego Czerkieskiego Obwodu Autonomicznego. J. Kałmykow był wybitnym uczonym, teoretykiem prawa, specjalistą w dziedzinie prawa cywilnego. Przez wiele lat prowadził działalność naukowo-badawczą i dydaktyczną w Saratowskim Uniwersytecie Prawnym (był nauczycielem m.in. prezydenta Karaczajo-Czerkiesji B. Ebziejewa). 26 marca 1989 roku uzyskał mandat deputowanego ludowego ZSRR. W 1993 roku został deputowanym do Dumy Państwowej

\footnotetext{
${ }^{8}$ Ibidem.

${ }^{9}$ Zob. B. Anderson, Wspólnoty wyobrażone: Rozważania o źródtach i rozprzestrzenianiu się nacjonalizmu, przeł. S. Amsterdamski, Kraków 1997.

${ }^{10}$ Zob. S. Shenfield, The Circassians - A Forgotten Genocide?, w: Massacre in History, red. M. Levene, P. Roberts, New York 2006.

${ }^{11}$ Zob. M. Bliev, Czerkiesja i Czerkiesy XIX wieka. Kratki Očerk Istorii, Moskva 2011; M. Budaj, ,,Velikaâ Čerkesiâ" - poslednij šag....

${ }^{12}$ Zob. strona internetowa stowarzyszenia: www.adyge-hase.ru.

${ }^{13}$ Zob. T. Muzajev, Vybory glavy Karačaevo-Čerkiesii...
} 
FR. Od 5 kwietnia 1993 roku do 7 grudnia 1994 roku był ministrem sprawiedliwości Federacji Rosyjskiej ${ }^{14}$. J. Kałmykow zdobył sławę jako nieprzejednany krytyk wojny w Czeczenii. Cieszył się powszechnym autorytetem nie tylko na Kaukazie, ale i w całej Rosji. Był politykiem umiarkowanym, stroniącym od postulatów radykalnych - funkcję przewodniczącego traktował przede wszystkim honorowo. Był jednak gwarantem, że organizacja nie będzie ewoluować w kierunku radykalnego separatyzmu. Na Czele Międzynarodowego Stowarzyszenia Czerkieskiego stał w latach 1990-1993 i od 1996 roku do swojej śmierci w roku $1997^{15}$.

Pod koniec 1994 roku nastroje w czerkieskim ruchu nacjonalistycznym ponownie uległy radykalizacji. Lider działającej w Karaczajo-Czerkiesji sekcji Adyge Chase Borys Akbaszew 24 grudnia 1994 roku zorganizował I Zjazd Narodu Czerkieskiego, który powołał do życia Komitet Wykonawczy Narodu Czerkieskiego ${ }^{16}$. Kongres powrócił do wysuwanego wcześniej przez Czerkiesów postulatu oderwania regionu od Karaczajo-Czerkiesji. Pod koniec lat dziewięćdziesiątych B. Akbaszew został wybrany głową Międzynarodowego Stowarzyszenia Adygskiego „Adyge Chase ${ }^{\text {,17 }}$.

Ruch cały czas pozostawał strukturą niesformalizowaną. Dopiero po zwycięstwie W. Siemionowa w wyborach głowy republiki czerkieskie struktury nacjonalistyczne zostały oficjalnie zarejestrowane na terenie regionu. Międzynarodowe Stowarzyszenie Czerkieskie „Adyge Chase" uzyskało osobowość prawną w marcu 2001 roku, gdy zostało zarejestrowane przez Ministerstwo Sprawiedliwości FR.

Warto zauważyć, że panczerkieski ruch nacjonalistyczny nie jest jednolity - działacze niepodległościowi mają odmienne cele i strategie, różni ich stopień radykalizmu wysuwanych postulatów ${ }^{18}$. Niezależnie od Międzynarodowego Stowarzyszenia Czerkieskiego „Adyge Chase" na terenie Kaukazu północno-zachodniego od 2008 roku działa nieformalna organizacja nacjonalistyczna o bardzo podobnej nazwie: Ruch Społeczny „Adyge Chase”, która ma swój oddział w Karaczajo-Czerkiesji ${ }^{19}$. Organizacja stawia sobie za cel zjednoczenie wszystkich Adygów i otwarcie głosi hasła separatystyczne. Ruch Społeczny „Adyge Chase” w Karaczajo-Czerkiesji ma charakter nieformalny, a jego struktury są częściowo utajnione. Liderem organizacji w regionie jest Abazyjczyk Muchamed Czerkiesow. Ruch Społeczny „Adyge Chase” Karaczajo-Czerkiesji organizował zjazd ruchów panczerkieskich Kaukazu Zachodniego w listopadzie 2008 roku, na którym przyjęto oświadczenie o konieczności zjednoczenia narodów adygskich ${ }^{20}$. W 2010 roku organizacja patronowała szeregowi inicjatyw propagandowych mających na celu koordynację działań wszystkich czerkieskich pannacjonalistów podczas spisu powszechnego w Federacji Rosyjskiej. Celem przedsięwzięcia było przekonanie przedstawicieli narodów adygskich do tego, aby wszyscy oni deklarowali narodowość czerkieską, a nie np. kabardyjską, adygejską czy abazyjską. Celem ruchu było wykorzystanie spisu powszechnego jako okazji do zademonstrowania jedności wszystkich Adygów oraz przeprowadzenia kampanii na rzecz czerkieskiej świadomości narodowej.

\footnotetext{
${ }^{14}$ Zob. J. Kalmykov, Trudy. Statii. Vystupleniá, http://www.privlaw.h1.ru/kalmykov.html (8 marca 20012 r.).

${ }^{15}$ Ibidem.

${ }^{16} \mathrm{Na}$ czele ruchu staną lider Adyge Chase B. Akbaszew.

${ }^{17}$ Zob T. Muzaev, Vybory glavy Karačaevo-Čerkiesii...

${ }^{18}$ Zob. K. Kazenin, Čerkiesskij raskol: bor'ba za vlast' ili za novye granicy na Kavkaze?, http://www.regnum.ru/news/1154649.html (15 marca 2012 r.).

${ }^{19}$ Strona internetowa organizacji: www.adyge-hase.ru (15 marca 2012 r.).

${ }^{20}$ Zob. Obščestwiennyje organizacii podderŽali ideu obedineniâ čerkesov (Karačaevo-Čerkesiâ), http://www.regnum.ru/news/1087953.html (15 marca 2012 r.).
} 
Ruch Społeczny „Adyge Chase” Karaczajo-Czerkiesji wydał w tej sprawie następujące oświadczenie:

Od 14 do 25 października 2010 roku w państwie przeprowadzany będzie ogólnorosyjski spis powszechny. Wzywamy każdego Czerkiesa do udziatu w tej ogólnorosyjskiej akcji. Wasz udziat w spisie powszechnym będzie wyrazem odpowiedzialności obywatelskiej przed dzisiejszym społeczeństwem i następnymi pokoleniami, a taki̇e wyrazem wielowiekowych autentycznych historycznych, geograficznych i społeczno-ekonomicznych tradycji narodu czerkieskiego. Jesteśmy pewni, że spis powszechny potwierdzi jednoczenie się naszego narodu. Od rezultatów spisu bezpośrednio zależy nasza wspólna przyszłość oraz przyszłość naszych dzieci. W tym celu koniecznie trzeba prawidłowo wypetnić kartę spisu i uważać, żeby w rubryce numer 7 „, Przynależność narodowościowa” odpowiedzieć CZERKIES/CZERKIESKA, a w rubryce 9 ,język ojczysty” odpowiedzieć CZERKIESKI'.

Wraz z upływem czasu czerkieski ruch nacjonalistyczny staje się coraz radykalniejszy. Radykalizacja postulatów charakterystyczna jest dla młodego pokolenia działaczy panczerkieskich, ukształtowanych ideologicznie już po upadku ZSRR, którzy często wyrażają niezadowolenie z zachowawczej linii oficjalnych organizacji czerkieskich. Jako przykład można przytoczyć tu kongres młodzieży czerkieskiej, który odbył się we wrześniu 2009 roku w Czerkiesku. Zgromadzeni delegaci wyrazili niezadowolenie z działalności ruchu narodowego, który w ich przekonaniu przez ostatnie dziewięć lat miał działać w sposób niesatysfakcjonujący. W przekonaniu młodych Czerkiesów istnieje konieczność gruntownej restrukturyzacji ruchu, która powinna przybrać postać zmiany pokoleniowej. Podkreślili konieczność włączenia świadomej narodowo młodzieży do ciał kierowniczych oficjalnych organizacji narodowych. Delegaci wezwali do podjęcia zdecydowanych działań na rzecz przezwyciężenia podziałów narodowych, konsolidacji, zapobieżeniu zanikowi języka czerkieskiego, wymuszenie na Rosjanach uznania ludobójstwa Czerkiesów w XIX wieku. Akcentowano konieczność wspierania kultury, tradycji i tożsamości ${ }^{22}$. Podczas konferencji powołano do życia Komitet Koordynacyjny Młodzieży Czerkieskiej i przyjęto ośmiopunktową rezolucję $e^{23}$.

Poparcie dla dążeń separatystycznych ruchu panczerkieskiego nie jest wyłącznie fenomenem lokalnym. Wyjątkowo aktywną działalność propagandową i lobbingową prowadzą działacze diaspory czerkieskiej w Stanach Zjednoczonych, Kanadzie, Turcji i Izraelu. Sprawa „zapomnianego ludobójstwa”, którego Rosjanie mieli dokonać na narodzie czerkieskim, od dawna budzi zainteresowanie amerykańskich ośrodków naukowo-analitycznych. Na początku XXI wieku na renomowanych uniwersytetach w USA odbyła się seria konferencji poświęconych losom narodu czerkieskiego, w których uczestniczyli działacze diaspory adygskiej. Organizacją, która najaktywniej zajmuje się propagowaniem problematyki czerkieskiej na międzynarodowym forum naukowych jest bliska amerykańskiej prawicy neokonserwatywnej Jamestown Foundation $^{24}$. Czołowymi uczestnikami projektów organizowanych przez tę fundację są były dyrektor prywatnej agencji wywiadowczej RAND Corporation Paul Henze, były ekspert CIA ds. Eurazji Paul Goble i profesor politologii Uniwersytetu Massachusetts

${ }^{21}$ Vnimanie! Perepis'!, http://adyge-hase.ru/news/vnimanie_perepis/2010-10-15-4 (16 marca 2012 r.).

${ }^{22}$ Zob. P. Goble, Window on Eurasia: Circassian Youth Seek „Radical” Renewal of National Movement, http://windowoneurasia.blogspot.com/2009/09/window-on-eurasia-circassian-youth-seek.html (16 marca 2012 r.).

${ }^{23}$ Pełny tekst rezolucji w języku angielskim: Resolution from Cherkessia (Adyghe) Youth, http://www.justicefornorthcaucasus.com/jfnc_message_boards/circassia_adiga.php?entry_id=1252942909\&title=resolution-forum-cherkessia-(adyghe)-youth\&comments $=$ comments (15 marca 2012 r.).

${ }^{24}$ Zob. www.jamestown.org (15 marca 2012 r.). 
Matthew Light. Jamestown Foundation udziela aktywnego wsparcia organizacjom diaspory czerkieskiej odwołujących się do panadygskiego nacjonalizmu takim jak Chaszi Bajram w Turcji, Zijada Chadżo w USA czy międzynarodowy Czerkieski Instytut Kulturalny. Do szczególnie radykalnych separatystów czerkieskich należy Zamir Szuchow, prezes Światowego Braterstwa Adygów z siedzibą w Los Angeles ${ }^{25}$. Celem międzynarodowych ośrodków geopolitycznych wspierających separatyzm czerkieski jest pozbawienie Rosji dostępu do Morza Czarnego, co byłoby równoznaczne z utratą statusu mocarstwa regionalnego.

„Kwestia czerkieska” zyskała aktualność w kontekście decyzji 119 sesji Międzynarodowego Komitetu Olimpijskiego o przyznaniu miastu Soczi prawa do organizacji Zimowych Igrzysk Olimpijskich w 2014 roku. Czarnomorski kurort leży na terytoriach historycznej Czerkiesji. Działacze adygskiej diaspory uznali decyzję MKOl za wygodny pretekst do nagłośnienia swoich postulatów.

4 października 2007 roku w Stanach Zjednoczonych i Turcji jednocześnie odbyły się demonstracje przed rosyjskimi przedstawicielstwami dyplomatycznymi. Największe światowe kanały telewizyjne transmitowały przebieg protestów, podczas których wznoszono hasła Soczi - ziemia ludobójstwa, Nie krwawym igrzyskom, Wolność i prawo dla Czerkiesji ${ }^{26}$.

19 maja 2011 roku gruziński parlament jednogłośnie przyjął rezolucję, w której uznał, że w XIX wieku rosja dopuściła się ludobójstwa na narodzie czerkieskim ${ }^{27}$. Rosjanie odebrali gest gruzińskich parlamentarzystów jako zapowiedź prób podsycania nacjonalizmu panczerkieskiego i sabotowania igrzysk olimpijskich w Soczi.

Należy zauważyć, że stosunek ruchu panczerkieskiego do Gruzji jest bardzo złożony. Podczas konfliktu zbrojnego z 2008 roku Międzynarodowe Stowarzyszenie Czerkiesów „Adyge Chase” i organizacje nacjonalistyczne działające w poszczególnych republikach wyraźnie angażowały się we wspieranie separatyzmu abchaskiego. Działania armii gruzińskiej na rzecz aneksji zbuntowanych republik spotykały się wówczas ze zdecydowanym potępieniem Czerkiesów ${ }^{28}$. Decyzja gruzińskiego parlamentu została jednak przyjęta entuzjastycznie, a wśród rosyjskich politologów rozpowszechniona jest teza, zgodnie z którą bardzo prawdopodobny jest sojusz władz gruzińskich z separatystami czerkieskimi mający na celu osłabianie wpływów Rosji na Kaukazie, między innymi poprzez sabotowanie igrzysk olimpijskich w Soczi ${ }^{29}$.

Do nasilenia protestów ludności adygskiej w Karaczajo-Czerkiesji doszło w listopadzie 2009 roku po ukazaniu się w miejscowej gazecie Express-Post artykułu prasowego, którego autor zaprzeczył, że pierwsi historyczni zdobywcy Elbrusu byli Czerkiesami, poddał też w wątpliwość ratowanie Żydów przez Czerkiesów podczas II wojny światowej. Panczerkieskie organizacje nacjonalistyczne zapowiadały masową demonstrację w Czerkiesku, która została zakazana przez władze republikańskie z uwagi na ryzyko rozprzestrzeniania się wirusa H1N1. Decyzja władz wywołała falę protestów czerkieskiej diaspory na świecie i zmasowaną ofensywę propagandową przeciw „opresji narodu czerkieskiego”. Mimo zakazu 20 listopada 2009 roku odbył się nielegalny wiec w Czerkiesku, na którym wznoszono separatystyczne

\footnotetext{
${ }^{25}$ Zob. W. Guliewicz, Geopolityka Wielkiej Czerkiesji, http://www.geopolityka.org/komentarze/713-geopolityka-wielkej-czerkiesji (15 marca 2012 r.).

${ }^{26}$ Zob. A. Šmulevič, Krov Krasnoj Polâny. Olimpiada na zemle genocida kak lovuška na russkogo medviedâ, http://www.geopolitica.ru/Articles/289/ (8 marca 2012 r.).

27 Zob. E. Barry, Georgia Says Russia Committed Genocide in 19th Century, „New York Times”, 20 maja 2012 r.

${ }^{28}$ Zob. Mieždunarodnaâ Čerkeskâ̂ Asociaciâ: Rukovodstvo Gruzii protivopostavilo svoj narod vsem narodom Kavkaza, http://regnum.ru/news/1039749.html (16 marca 2012 r.).

${ }^{29}$ Zob. A. Šmulevič, Krov Krasnoj Polâny...
} 
hasła. Liderem ruchu protestu stał się młody radykalny działacz czerkieski Timur Żużujew, który miał powiedzieć, że prawo do demonstracji To nie jest wola jednego czy dwóch ludzi. To jest wola narodu. Mamy prawo mówić to, co myślimy ${ }^{30}$.

Wydarzeniem, które zbulwersowało opinię publiczną i stało się przyczyną przypływu kolejnej fali nacjonalizmu czerkieskiego było zabójstwo przewodniczącego organizacji młodzieżowej Ruchu Społecznego „Adyge Chase” Karaczajo-Czerkiesji Asłana Żukowa. Ten urodzony w 1973 roku sportowiec (zawodnik mieszanych sztuk walki) i przedsiębiorca uznawany był za lidera młodego, bardziej radykalnego pokolenia czerkieskich nacjonalistów. 14 marca 2010 roku został zastrzelony przez nieznanego napastnika ${ }^{31}$. Zbrodnia stała się przyczyną licznych demonstracji i pikiet, podczas których żądano odnalezienia i ukarania sprawców oraz wysuwano postulaty separatystyczne ${ }^{32}$. Organizatorami demonstracji byli T. Żużujew i M. Czerkiesow - reprezentanci młodszego i starszego pokolenia czerkieskich działaczy nacjonalistycznych.

Separatyzm czerkieski jest przez współczesnych rosyjskich uczonych i polityków uznawany za jedno z największych zagrożeń dla integralności terytorialnej Federacji Rosyjskiej. Za przykład może tu posłużyć opinia członka Rosyjskiej Akademii Nauk Michaiła Zalichanowa:

Oddziaty międzynarodowej organizacji Adyge Chase istnieja w wielu państwach zachodnich i bliskowschodnich, we wszystkich wyzej wymienionych republikach [Kabardo-Bałkarii, Karaczajo-Czerkiesji i Adygei - przyp. aut.], a nawet w Moskwie-i wszędzie tam prowadza aktywnq działalność. [...] One występuja w charakterze organizacji politycznych, formulujacych nowa ideologie narodowa (pod wieloma względami-szownistycznq i separatystyczna), wysuwajaca żadania terytorialne, usilujacq wpływać na regionalne, a nawet federalne organy władzy. Ktoś może powiedzieć, że przyświeca temu cel stworzenia zjednoczonej, monoetnicznej republiki w ramach Rosji. Dlaczego zatem właśnie te organizacje prowadzq aktywnq walkę na rzecz uzyskania międzynarodowego statusu rozdzielonego narodu, propaguja tezę o ludobójstwie narodu czerkieskiego dokonanym przez Rosjan w XIX wieku, głoszq hasło „, Nie dla igrzysk olimpijskich na ziemi ludobójstwa" i czyniq wszystko co moga, aby sprowokować nowy konflikt na Kaukazie ${ }^{33}$ ?

Jak pisze izraelsko-rosyjski politolog A. Szmulewicz, wśród czerkieskich działaczy politycznych orientacji nacjonalistycznej wyróżnić można dwie kategorie. Pierwsza dąży do wywalczenia najpierw szerokiej autonomii, a następnie pełnej niepodległości Czerkiesji. Działacze ci upatrują głównego sojusznika w państwach Zachodu, który w ich przekonaniu powinien wymusić na Rosji ustępstwa. Druga kategoria pozostaje lojalna wobec Rosji i dąży do realizacji swoich interesów w ramach prawa federalnego, licząc na możliwość sojuszu z Moskwą. Zdaniem politologa druga grupa jest liczniejsza ${ }^{34}$.

Na osobny opis zasługuje ruch separatystyczny czwartego co do liczebności etnosu Karaczajo-Czerkiesji, którym są Abazyjczycy. Narodowość ta należy do grupy abchazo-adygskiej. Abazyjczycy, za sprawą bliskości kulturowej i językowej, są tradycyjnie uznawani za bratni i sojuszniczy etnos Czerkiesów. Sojusz czerkiesko-abazyjski przybrał zorganizowane

\footnotetext{
${ }^{30}$ Zob. F. Tlisova, Circassians in Karachaevo-Cherkessia Plan Mass Protest, „Eurasia Daily Monitor”vol. 6, 2009.

${ }^{31}$ Zob. $V$ Čerkesske ubit odin iz liderov molodeŽnogo nacional'nogo dwiŽeniâ, http://www.regnum.ru/news/ 1262949.html.

${ }^{32}$ Zob. W Karačaevo-Čerkesii aktivisty , Adyge Hase” trebuut raskryt' ubijstvo Aslana Žukova, http://www.kavkaz-uzel.ru/articles/168706/ (16 marsa 2012 r.).

${ }^{33}$ M. Zalicharow, Rossiâ minus Kavkaz?, „Rossijskaâ Federaciâ siegodnâ”, 9 lipca 2010.

${ }^{34}$ Zob. A. Šmulevič, Dva lika čerkesskogo nacionalizma. Panoramnyj wzglâd, http://www.peoples-rights.info/ 2010/10/dva-lika-cherkesskogo-nacionalizma-panoramnyj-vzglyad/ (16 marca 2012 r.).
} 
formy w okresie kryzysu politycznego 1999 roku. Abazyjczycy masowo popierali wówczas czerkieskiego kandydata S. Dieriewa. Część przedstawicieli tego niewielkiego narodu identyfikuje się z ruchem panczerkieskim i działa w stowarzyszeniu „Adyge Chase”.

\section{Inne ruchy etnoseparatystyczne w Karaczajo-Czerkiesji}

Działalność separatystów adygskich należy analizować przede wszystkim w szerszym kontekście nacjonalizmu panczerkieskiego. Do wyjątków należy jednak kryzys polityczny 2005 roku, podczas którego stronami sporu byli wyłącznie Abazyjczycy i Karaczajowie. Kryzys został spowodowany przez wydarzenia z 23 czerwca 2005 roku, gdy mieszkańcy abazyjskiego aułu Kubina przeprowadzili akcję protestacyjna, która przybrała formę okupacji siedziby Zgromadzenia Narodowego Karaczajo-Czerkiesji. Przyczyną protestu stała się modyfikacja podziału administracyjnego republiki. Granica między Kubiną a sąsiednim miastem Ust-Dżeguta (zamieszkałym w większości przez ludność karaczajską) przeprowadzona została w taki sposób, że karaczajskiemu miastu przekazana została znaczna część ziem aułu, między innymi elektrociepłownia „Jużnyj”, która przynosiła miejscowemu budżetowi znaczny dochód. Pod naciskiem protestów Abazyjczyków parlament Karaczajo-Czerkiesji podjął decyzję o powołaniu do życia nowej jednostki - Regionu Abazyjskiego ${ }^{35}$. Przywódcą abazyjskiego ruchu narodowego był wówczas były oficer armii radzieckiej, weteran pierwszej wojny abchaskiej Muchammed Kilba.

Osobnym fenomenem ruchu narodu nogajskiego jest „Birlik” (,Jedność”), który stawiał sobie za cel przywrócenie integralności terytorialnej narodu nogajskiego i stworzenie struktury narodowo-państwowej w ramach RFSRR. Pierwszy zjazd organizacji nacjonalistów nogajskich odbył się w 1989 roku, jednak zorganizowaną strukturę ruch przybrał dopiero w 1991 roku. Aktywność ruchu była początkowo niewielka - w 2000 roku jego struktury zostały nawet przejściowo rozwiązane ${ }^{36}$. Podejmowano próby zjednoczenia Nogajców Karaczajo-Czerkiesji, Kraju Stawropolskiego, Obwodu Astrachańskiego i Dagestanu, które jednak spełzły na niczym. Przypływ nogajskiego nacjonalizmu ponownie nastąpił jednak w połowie pierwszej dekady XXI wieku. Ruch „Birlik” pod wodzą Magomeda Sanglibajewa zdołał doprowadzić do referendum w sprawie utworzenia Regionu Nogajskiego w ramach Republiki Karaczajo-Czerkieskiej, w którym wzięli udział mieszkańcy ośmiu wsi nogajskich. Referendum zakończyło się wyraźnym zwycięstwem zwolenników utworzenia nowego regionu, co oznaczało tryumf ruchu „Birlik” i jego przywódcy M. Sanglibajewa. Warto odnotować, że nogajski ruch narodowy nigdy nie był obiektem żadnych represji ze strony władz republiki, a prezydent M. Batdyjew otwarcie sprzyjał aspiracjom tego tureckiego narodu ${ }^{37}$.

\section{Radykalny islam polityczny w Karaczajo-Czerkiesji}

Osobnego omówienia wymagają stosunki wyznaniowe w Karaczajo-Czerkiesji, które również mogą mieć charakter konfliktogenny. Warto zauważyć, że rola tego czynnika jest

\footnotetext{
${ }^{35}$ Zob. A. Sanglibaev, Ètnopolitièeskie processy...

${ }^{36}$ Zob. T. Litvinova, Političeskie instytuty na severnom Kavkaze w kontekste razvitiâ rossijskoj gosudarstvennosti, Saarbrucken 2011, s. 70.

${ }^{37}$ Zob. K. Kazienin, Tihie konflikty..., s. 172.
} 
nieporównywalnie mniejsza od roli animozji między elitami etnoklanowymi i rosnącej popularności ruchów separatystycznych, wszystkie spośród których mają charakter w pełni świecki.

Islam sunnicki jest dominującym wyznaniem w Karaczajo-Czerkiesji - wyznaje go przeszło $62 \%$ mieszkańców regionu. Model religijności w republice jest charakterystyczny dla całego regionu Kaukazu Zachodniego. Karaczaje, jak i Czerkiesi uznają praktyki religijne za element życia prywatnego - znaczna większość mieszkańców republiki nie odczuwa potrzeby ostentacyjnego manifestowania pobożności.

Nieznaczna obecność religii w życiu społecznym i znikome poparcie dla idei radykalnego islamu politycznego odróżnia Kaukaz północno-zachodni od regionów takich, jak Dagestan, Czeczenia i Inguszetia:

Do islamu nie odwolywaty się natomiast ruchy narodowe republik Kaukazu Pótnocno-Zachodniego [...]. Religia była tam słabiej zakorzeniona, znacznie silniejsza pozycje miała też miejscowa nomenklatura, która zdołała utrzymać się u władzy. Kierownictwo tych republik traktowato islam jako lokalnq specyfikę - na równi z górskim folklorem - chociaż demonstrowało swoja religijność, m. in. poprzez udział w hadżdżu ${ }^{38}$.

W Karaczajo-Czerkiesji współpraca między wspólnotami muzułmańskimi a władzami państwowymi zawsze układała się harmonijnie. Od czasu W. Chubijewa wszyscy kolejni prezydenci republiki byli świeckimi muzułmanami, sporadycznie uczestniczącymi w uroczystościach religijnych, którzy jednak szanowali islam i blisko współpracowali ze strukturami religijnymi, jednocześnie dystansując się od idei „odrodzenia islamskiego” i przeciwdziałając wzrostowi popularności wahabizmu. I. Bierdijew jest powszechnie szanowany nie tylko w Karaczajo-Czerkiesji, ale także na całym Kaukazie Północnym - jego autorytet uznają także niemuzułmańscy mieszkańcy regionu. Warto jednak zauważyć, że praktyki religijne w Karaczajo-Czerkiesji są słabo zinstytucjonalizowane, a identyfikacja ludności z Duchowym Zarządem Muzułmanów Karaczajo-Czerkiesji jest raczej niewielka (za wyraziciela swoich interesów instytucję tę uważa zaledwie $6,2 \%$ Karaczajów oraz 8,8\% Czerkiesów) ${ }^{39}$. W życiu społeczno-politycznym republiki islam pełni rolę folklorystyczno-dekoracyjną.

Karaczajo-Czerkieski Instytut Islamski działa bardzo prężnie. Nauka w instytucie, będącym wyższą uczelnią teologiczną, trwa pięć lat. Program obejmuje pełny kurs języka arabskiego i teologii muzułmańskiej. Oprócz tego przy większości meczetów w regionie działają szkółki religijne (maktaby), które przygotowują do pełnego uczestnictwa w rytuałach, oraz - znacznie rzadziej - uczą elementów teologii i podstaw języka arabskiego. Przy największych meczetach działają dwuletnie szkoły koraniczne. Część młodzieży udaje się na studia religijne za granicę (głównie do Turcji, Arabii Saudyjskiej, Syrii, Jordanii, Egiptu i Pakistanu) ${ }^{40}$.

Religijność w Karaczajo-Czerkiesji, tak jak w całym regionie Kaukazu północno-zachodniego, jest raczej powierzchowna, a organizacje fundamentalistyczne nie cieszą się tu popularnością. Meczety są tu puste nawet podczas uroczystych piątkowych modłów. Odsetek mężczyzn zapuszczających brody i kobiet noszących chusty jest bardzo niewielki. Powszechnie spożywa się alkohol, który jest łatwo dostępny w sklepach i barach ${ }^{41}$.

Liberalny stosunek do kwestii wyznaniowych i powszechne uznawanie religijności za część życia prywatnego sprawia, że ekstremiści religijni nie cieszą się popularnością w Kara-

\footnotetext{
${ }^{38}$ Islam na obszarze postradzieckim, materiał analityczny Ośrodka Studiów Wschodnich, Warszawa 2003, s. 38.

${ }^{39}$ Ibidem, s. 45.

${ }^{40}$ Ibidem, s. 45-46.

41 Ibidem, s. 46.
} 
czajo-Czerkiesji. Działalność Partii Odrodzenia Islamskiego odwołującej się do idei wahabizmu w latach 1990-1994 pod wodzą radykalnego działacza politycznego i teologa Muhammada Bidżijewa należy uznać za epizod. Pod egidą partii powstała struktura religijno-polityczna określana jako „Imamat Karaczaja”. Wahabici usiłowali propagować swoje hasła wśród karaczajskich separatystów - wraz z zanikiem karaczajskiego ruchu nacjonalistycznego próby te stały się bezprzedmiotowe.

Innym wpływowym karaczajskim działaczem fundamentalistycznym był Ramzan Borłakow, który nawiązał ścisłą współpracę z czeczeńskim podziemiem wahabickim. W okresie wojny czeczeńskiej usiłował on organizować w republice ruch poparcia dla separatystów Dżohara Dudajewa. Wzywał muzułmanów Karaczajo-Czerkiesji do masowej wędrówki ( $m u$ hadżirstwa) do walczącej o niepodległość Czeczenii. Zdołał sformować karaczajski batalion, który uczestniczył w działaniach bojowych przeciw Rosji, którego większość uczestników - w tym sam R. Borłakow - zginęła podczas drugiej wojny czeczeńskiej ${ }^{42}$.

Słynną podziemną grupą ekstremistyczną był oddział Wachtanga Alijewa, wahabickiego działacza, który przeszedł trening w obozie szkoleniowym saudyjskiego bojownika Emira al-Chattaba. Grupa odpowiedzialna jest za liczne zabójstwa milicjantów, jednak złą sławę zyskała przede wszystkim za sprawą zamachu dokonanego na umiarkowanego imama Karaczajewska Abul-Kerima Bajramukowa. Grupa została unicestwiona podczas operacji specjalnej W grudniu 2006 r. $^{43}$

Dziś najbardziej wpływowym działaczem fundamentalistycznym w Karaczajo-Czerkiesji pozostaje M. Bidżijew, znany dziś powszechnie jako Szejk Mohammed Karaczaj. Pozostaje on krytykiem oficjalnych struktur religijnych z I. Bierdijewem na czele, lecz nie głosi już poglądów otwarcie ekstremistycznych i separatystycznych. Zrezygnował też z nawoływania do przemocy. W swoich odezwach i wywiadach nawołuje Karaczajów i Czerkiesów do wejścia na drogę odrzucenia grzechu i prawdziwej wiary wiodącej do zbawienia ${ }^{44}$. Mohammed Karaczaj jest dziś głosem idei „odrodzenia religijnego” w Karaczajo-Czerkiesji i reprezentuje radykalne kontrelity muzułmańskie.

Radykalny islam polityczny jest w Karaczajo-Czerkiesji zjawiskiem marginalnym. Wahabizm nigdy nie był tu popularny, jednak w ciągu ostatnich kilkunastu latach uległ całkowitej dyskredytacji. Republika Karaczajo-Czerkieska to region świecki - religia przenika się tu z polityką w nader niewielkim stopniu, służąc za rodzaj swoistego ,folklorystycznego ornamentu" podczas niektórych uroczystości państwowych. Nie zmienia to faktu, że islam sunnicki - jakkolwiek wyznawany powierzchownie i praktykowany bardzo nieregularnie - pozostaje ważną częścią tożsamości narodowej i kulturowej zarówno Karaczajów, jak i Czerkiesów oraz Abazyjczyków.

Położenie geopolityczne czyni Karaczajo-Czerkiesję szczególnie istotną z punktu widzenia procesów wpływających na destabilizację polityczną Kaukazu Północnego. Ta niewielka republika może stać się zarzewiem konfliktu, który zdestabilizuje cały obszar Kaukazu i za-

\footnotetext{
${ }^{42}$ Zob. M. Vatchagaev, Karachay Jamaagat: History, Reality, and Perspective pt. 1, http://www.jamestown.org/single/?no_cache=1\&tx_ttnews\%5Btt_news\%5D=4203 (17 marca 2012 r.).

${ }^{43}$ Zob. E. Kratov, N. Kratova, Islam v Karačaevo-Čerkesskoj..., s. 76.

${ }^{44}$ Zob. Šejh Muhammad Karačaj: Religiâ bez posrednikov ne dopuskaet formalnostej, http://oodrin.ru/?p=2698 (17 marca 2012 r.).
} 
grozi integralności terytorialnej Federacji Rosyjskiej. Wpływy wahabickiego podziemia terrorystycznego $\mathrm{w}$ republice są znikome, a głównym czynnikiem destabilizacji pozostają tu konflikty etniczne i ruchy separatystyczne. Karaczajo-Czerkiesja jest swoistym epicentrum panadygskiego ruchu separatystycznego, który potencjalnie może zainicjować proces oddzielenia się Kaukazu Północnego od Federacji Rosyjskiej.

Klucz do rozwiązania problemów Karaczajo-Czerkiesji stanowi właściwa polityka etniczna, równoważąca ambicje wszystkich grup narodowościowych i uwzględniająca znaczenie tradycji. Tożsamość etniczna i klanowa musi zostać wpisana w szerszy projekt federalnej tożsamości obywatelskiej polietnicznej Rosji. Nie wiemy na razie jaki kurs polityczny obierze nowy prezydent Karaczajo-Czerkiesji - Raszyd Tiemriezow. Od jego strategii, woli politycznej oraz umiejętności harmonijnej współpracy z Moskwą zależy przyszłość nie tylko samej republiki, ale także całego Kaukazu Północnego i Federacji Rosyjskiej.

\section{Summary}

\section{The factors of political destabilization in Karachay-Cherkessia: ethnic separatism and religious fundamentalism}

The Republic of Karachay-Cherkessia is among the most unstable entities of the Russian federation. Whereas the ideas of radical political Islam enjoy little popularity there, the ethnic structure is exceptionally complex, which is not reflected in the model of territorial administration. The scale of corruption and nepotism of the local elite is enormous. The relations between the two titular ethnicities of Karachay-Cherkessia abound in mutual prejudices and distrust, or even hostility. The current model of a two-nationality republic is an element of the Soviet legacy, originally introduced in order to overcome ethnic particularism. The decline of the Soviet model of state fostered ethnic particularism and separatism, which applied to Karachays and Cherkessians alike at the turn of the nineteen-eighties. At present, Karachay separatism is a marginal phenomenon, while the influence of the Pan-Cherkessian movement has been consistently growing, posing an increasing threat to the territorial integrity of the Russian Federation. The author characterizes various dimensions of ethnic separatism in Karachay-Cherkessia and analyzes the reasons for the weakness of the armed Islamist underground in this Caucasian republic. 
